\title{
マイクロバンプ接合技術の開発動向
}

\author{
鳥山 和重*, 岡本 圭司*, 小原 さゆり*, 折井 靖光*
}

\section{Development Status of Micro-Bump Interconnection Technologies}

Kazushige TORIYAMA*, Keishi OKAMOTO*, Sayuri KOHARA*, and Yasumitsu ORII*

*日本アイ・ビー・エム株式会社東京基礎研究所（干 242-8502 神奈川県大和市下鶴間 1623-14）

* Tokyo Research Laboratory, IBM Japan, Ltd. (1623-14 Shimotsuruma, Yamato-shi, Kanagawa 242-8502)

\section{1.はじめに}

半導体デバイスは, その誕生以来, 情報化社会の発展と ともに進化を続けてきた。これは，1965年にインテルの ゴードン・ムーアが唱えた「半導体に集積されるトランジ スタの数は 1 年で 2 倍のペースで増加する」（以後, 1 年半 で2倍に修正）という「ムーアの法則」とほぼ同じペース

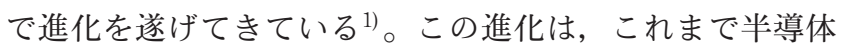
の微細化技術に支えられて実現してきた。しかし, 最近で は, 平面的 (2D)だけでなく, 垂直的(3D)にも物理的寸法を 縮小することで高密度化をはかり, 半導体デバイスの高速 化・高機能化・低消費電力化を実現させるという, 従来の スケーリング則を踏襲するという意味で「More Moore」と いう概念が導入されている。現在, 業界で最も注目を集め ているシリコン貫通ビア (Through-silicon via: TSV)形成技 術を活用した 3 次元積層化デバイスは，この「More Moore」 の流れの1つである。また, 必ずしも「ムーアの法則」に 従ってスケーリングしない機能（受動素子, センサなど） をデバイスに組み込み，付加価值を高めるという「More than Moore」という概念も導入されている ${ }^{2)}$ 。現在, 「More

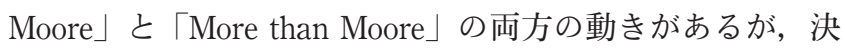
してどちらかに集約されるものではなく両方向のアプロー チで研究・開発が進められていくと考えられている。そし て, いずれの場合も実装する際の接続ピッチの微細化の動 きはさらに進むことが予測されている。これにより，これ まで以上に接合技術の難易度は上がることが容易に想像で きる。また, 従来の接合方式では対応できなくなる領域が でてくるため, 微細化に対応した新しい接合技術の研究 · 開発が強く求められている。

\section{2. マイクロバンプ接合技術の課題}

Fig. 1に今後のフリップチップ接合に関するトレンドを 示す。 SiP (System in Package) 分野で数多く使用されている ペリフェラルタイプの接合は, ワイヤボンディング・イ
メージのチップをフリップチップ化する技術であるが，こ れまで金一はんだ接合方式により $50 \mu \mathrm{m}$ ピッチ程度の非常 に微細ピッチでの量産が行われてきた。最近では金価格の 上昇, $\mathrm{I} / \mathrm{O}$ 数の増加, 電気特性の向上などの理由により, Cu Post Bump を用いた接合方式に切り替わりつつあるが, さらなる微細ピッチ化に対応したバンプ接合技術開発が積 極的に行われている。一方, CPUや ASICなどの高性能 · 高信頼製品に数多く用いられているC4 (Controlled Collapse Chip Connection) $)^{3)}$ に代表されるエリアアレイタイプの接合 は, $150 \mu \mathrm{m}$ ピッチ前後で量産が行われており, 現時点では それほど極端には微細ピッチ化が進んでいない。しかし， 現在, さらなる高密度化を実現するために，TSV技術を活 用した 3 次元積層化デバイス開発が積極的に推し進められ ている。最近では $20 \mu \mathrm{m}$ ピッチでの接合評価結果の報告4),5) もあり, エリアアレイタイプの接合も 3 次元積層デバイス の出現でこれまでと比較して格段に微細な接合が必要な世 界へと移行しつつある。このように，バンプピッチの微細 化の流れはこの先も進行していくが，この際，さまざまな 実装上の課題が生じる。Fig. 2 は現状のC4 バンプでの接合 部と 3 次元積層時の接合部のスケール比較を行ったもので あるが，微細化により接合部のはんだ体積が大幅に減少し， 接合部のはんだがすべて金属間化合物 (IMC) 化する (IMC

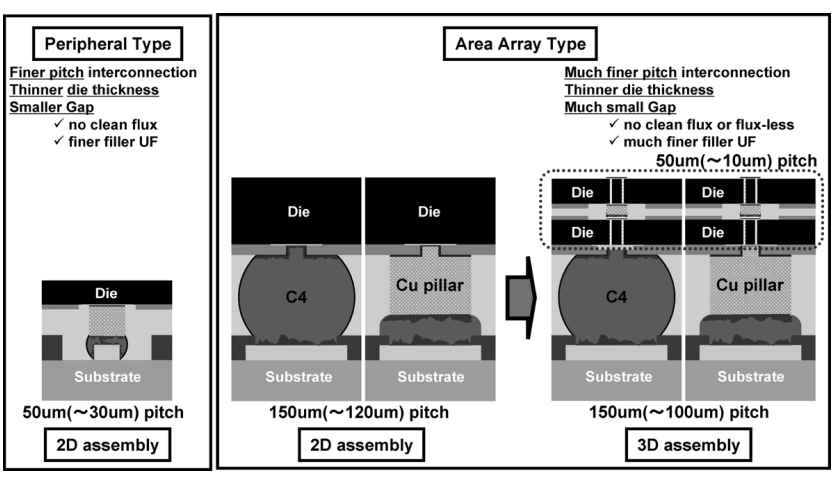

Fig. 1 Trend of interconnection technology 

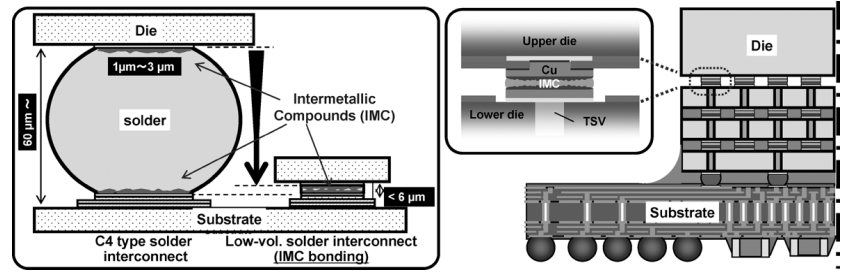

Fig. 2 Interconnection comparison (C4 vs micro-bump)

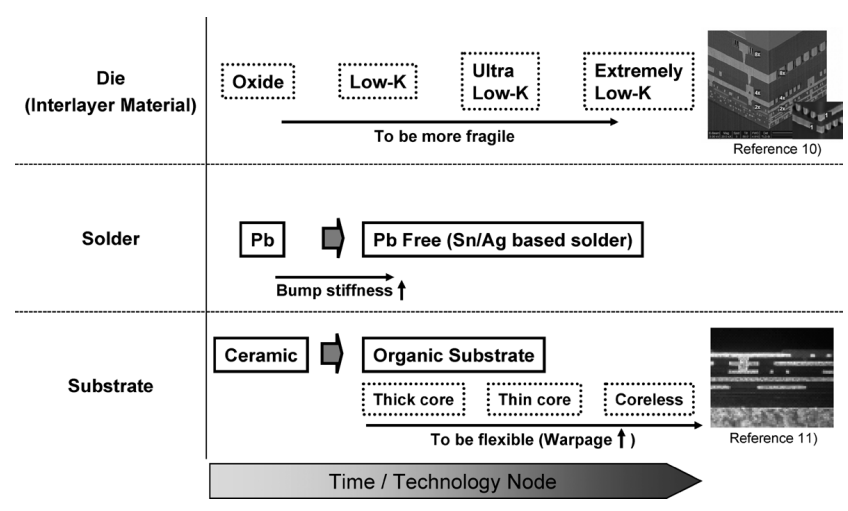

Fig. 3 Future package trend (CPI (Chip Package Interaction) challenge)

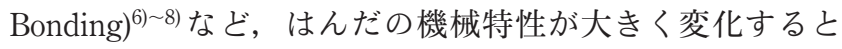
考えられる。よって, 接合部の信頼性を十分に検討したう えで，使用するはんだ組成やバンプ構造を決定することが 重要となる。また, 基板(Die) とのギャップが狭くなってい くことで, CUF (Capillary Underfill)方式では, Underfillを Die 底面に十分に充填することが困難となるため, Pre-Applied Underfill方式などの検討が必須となる。ほかにも, 放 熱やエレクトロマイグレーションの課題, 微細接合部の検 査の課題などが存在するが，一方で，チップとパッケージ の相互干涉である CPI (Chip Package Interaction) ${ }^{9)}$ に関して 屯十分に考慮しておく必要がある。Fig. 3 は, 今後のパッ ケージトレンドを示したものであるが, 半導体デバイスの 微細化に伴いBEOL (Back-End-of-Line)の層間絶縁材料とし て Low-k 材やUltra-Low-k材が使用されることで, BEOLの 機械強度はこれまでこ比較して低下する。また，接合部は， 鉛フリー化に伴いこれまでのはんだと比較して硬くて延性 の低い材料となる。これにより, チップに負荷されるスト レスは増加する。さらに, プリント配線板に関しては, 電 気特性の向上や低コスト化のためにコア厚が薄くなり, 最 終的にはコアレスになることで基板の反りは増大し，チッ プや接合部に負荷されるストレス増加が見込まれる。つま り, ピッチの微細化に対応した技術開発を進める際, より 繊細になっていく半導体デバイスに対して負荷されるチッ プとプリント配線板の CTE 差に起因するストレスを低減さ せることも考慮した技術開発が強く求められる。ここで, これらの現状を踏まえて, いくつかの技術内容を紹介する。
3. Cu Post Bumpを使用したフリップチップ接合技 術

さきに述べたように，ペリフェラルタイプのフリップチッ プ接合は，従来の金一はんだ接合方式からCu Post Bump を 用いた接合方式に切り替わりつつある。この際の実装方法 は, 「Reflow + CUF $」$ 方式と「Pre-applied Underfill+Thermal Compression Bonding」方式の 2 つが挙げられる。Fig. 4 に両工法のプロセスフローを示す。また，Table 1 に両工法 の特徴をまとめた比較表を示す。「Reflow $+\mathrm{CUF} 」$ 方式は, C4 バンプ実装にも採用されている非常に量産性の高い工法 である。IBMでは，ワイヤボンディング用のアルミニウム パッド表面に，電気めっき法により形成した金属 $(\mathrm{Cu})$ 層と はんだ層を有する 2 層構造バンプを用いることで，基板側

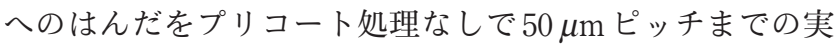
装プロセス開発を完了している。この実装方式をC2 (Chip

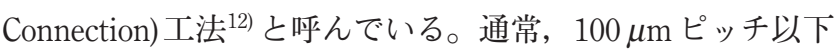
のプリント配線板の場合, フリップチップ部のソルダーレ ジスト開口は個別開口できず，スリット形状の開口となる。 これにより, はんだが $\mathrm{Cu}$ パッド上に流れ出すため, Die と プリント配線板間のギャップを確保することが困難となる が，リフロー時に溶融しない金属ポストを用いることでこ のギャップの確保が可能となる。また，金属ポストの設計 次第で，この高さは自由に変更できる。本方式は，非常に シンプルでかつ既存のインフラが使えるメリットがあるが, 反りの大きなプリント配線板への接合や $100 \mu \mathrm{m}$ 以下の薄い Dieでの接合に課題がある。また, CUF方式でUnderfillを 供給するため, $50 \mu \mathrm{m}$ ピッチ未満の微細ピッチ・狭ギャッ プへの対応が課題になると予測されている。一方,「Pre-applied Underfill+Thermal Compression Bonding」方式は，フ リップチップボンダを用いて，はんだ接合とUnderfill封止 を同時に実施する工法であるため，これらの課題を解決す ることができる工法として注目されている。また，はんだ 接合の際にすでにUnderfill封止されている状態にあるため, Dieの層間絶縁膜(Low-k膜)に負荷されるストレスを低減で きる効果も期待できる。この工法には，Die側にあらかじ め B-Stage 状態の Underfillを供給しておく OBAR (OverBump Applied Resin)工法 ${ }^{13)}$ や，プリント配線板にB-Stage 状態の Filmあるいはペースト状の Underfill を供給する方法 などがあるが，いずれの方法もプロセス管理が困難であり， 安定したプロセスの実現のためには, Underfill材料の開発 が重要な要素となる。また，実装サイクルタイムが長くな るため，今後の発展のためにはこの時間短縮が非常に大き な課題となっている。しかしながら, Die と基板間が数ミ クロンのギャップとなるような世界にはCUF方式では対応 できない可能性が高いため, Pre-applied Underfill技術は必 須な技術となると考えられる。

このように，Cu Post Bump はピッチの微細化に適した構 
造であるといえる。また，はんだバンプと比較してエレク トロマイグレーション特性に優れた構造であるため, 3 次 元集積化デバイスの接合にも採用されはじめている。しか し, 一方で, はんだバンプよりも High Modulus となるた め, CPIには不利な構造となる。よって, さらなる微細化 が進む 3 次元集積化デバイスへの適用のためには, CPIを 考慮したバンプ構造やはんだ組成の最適化を行うことが鍵 になると考えられる。

\section{3 次元集積化デバイスにおけるマイクロ接合技術}

TSV 技術を活用したシリコン積層技術 ${ }^{14), 15)}$ は，半導体デ バイスの高速化・高密度化 · 小型化の切り札として期待さ

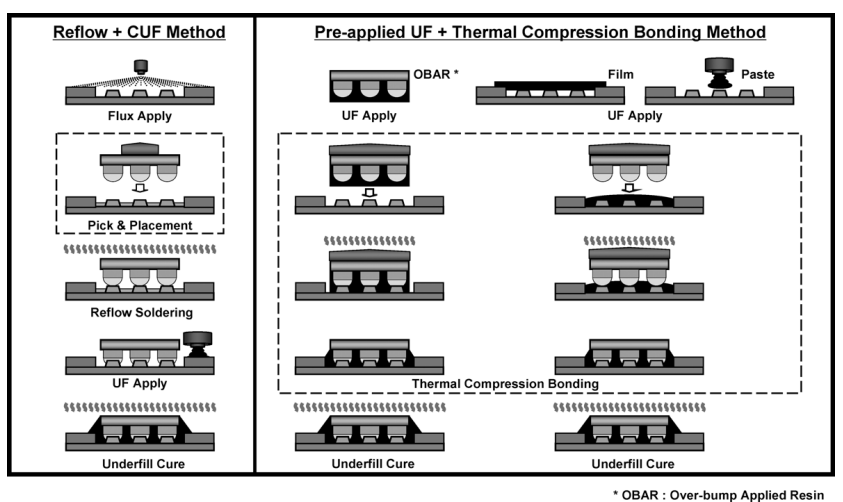

Fig. 4 Process flow comparison for $\mathrm{Cu}$ post bump assembly
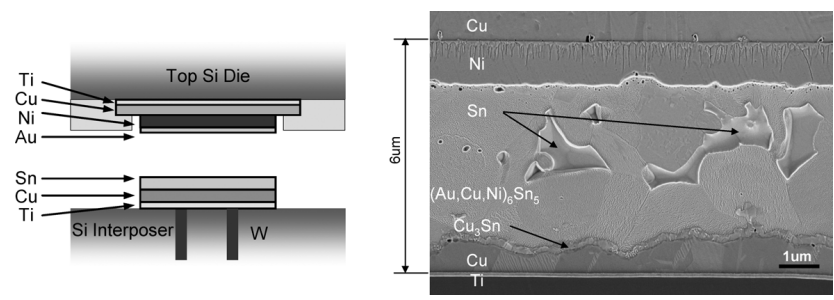

Fig. 5 Micro-bump interconnection
れている。この際の最小接合ピッチはいずれ $10 \mu \mathrm{m}$ 以下に なると予測されているが，基本的にシリコン間での接合と なるので，CTE差に起因するストレスが理論上発生しない ため，少ないはんだ量でも良好な接合が可能と考えられて いる。Fig. 5 は Ni-Auパット上に高さ約 $6 \mu \mathrm{m}$ の $\mathrm{Cu}-\mathrm{Sn}$ バン プを実装した接合例を示すが，非常に微量なはんだでもク ラックなどが発生せず，良好なはんだ接合が形成できてい ることがわかる。なお，一部で $\mathrm{Sn}$ が観察されているが，接 合直後の状態ですでに大部分が IMC 化していることが確認 できる。このように，シリコンーシリコン間の接合であれ ば，バンプの微細化が進んでも接合信頼性に大きな問題は 生じない。しかし，最終パッケージとして完成させるため にはプリント配線板との接合が必要となるため，この際に 発生するプリント配線板との CTE 差に起因するストレスの 影響を十分に検討しておくことが重要である。Fig. 6 にプ リント配線板にStacked Die が実装された 3 次元FEM (Finite Element Method) モデルとシミュレーション結果を示す。な お，一般に TSV を含む Si Interposerの厚みは $100 \mu \mathrm{m}$ 以下 の薄いものが多いため厚みは $70 \mu \mathrm{m}$ としている。FEMによ る構造解析の結果から, Top Dieの厚みが薄いほど接合部 に負荷されるストレスが低減する傾向にあることがわかる。 また，使用するはんだ組成によって接合部に負荷されるス トレスが変化することも確認できる。ちなみに接合時に使 用するはんだ組成の影響は，われわれの評価でも実際に確 認できている。このように，3次元集積化デバイス評価を

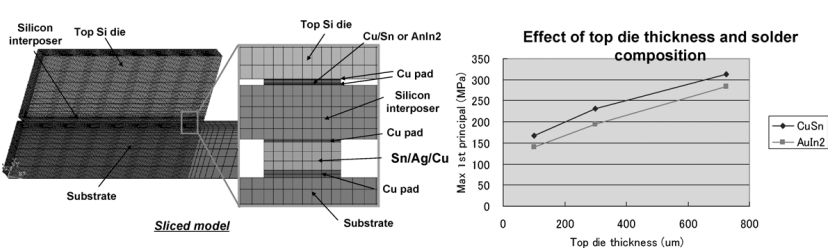

Fig. 6 3D quarter FEM model and simulation results (Effect of top die thickness and solder composition)

Table 1. Technology summary for Cu post bump assembly

\begin{tabular}{|c|c|c|}
\hline $\begin{array}{l}\text { Interconnection } \\
\text { technique }\end{array}$ & Reflow + CUF method & $\begin{array}{l}\text { Pre-applied UF + Thermal Compression } \\
\text { Bonding Method }\end{array}$ \\
\hline Pad surface finish & OSP, Au, Pre-solder & OSP, Au, Pre-solder \\
\hline Flip chip connect & $\begin{array}{l}\text { Pick \& Place (about } 2 \mathrm{~s})+ \text { Reflow } \\
\text { (One-time Connection) }\end{array}$ & $\begin{array}{l}\text { Thermal Compression Bonding } \\
\text { (One-by-One Connection) }\end{array}$ \\
\hline Underfilling technique & CUF & $\begin{array}{l}\text { Pre-applied UF } \\
(\text { Paste, Film, OBAR*) }\end{array}$ \\
\hline Pros & $\begin{array}{l}\text { - Tact time is short } \\
\text { - Equipment investment is small } \\
\text { - A bumping connection with SMD is possible }\end{array}$ & $\begin{array}{l}\text { - UF fillet length is small } \\
\text { - Low-k stress can be reduced } \\
\text { - Ultra-thin die }(<100 \mu \mathrm{m}) \text { is applicable } \\
\text { - Small gap/fine pitch joining is applicable }\end{array}$ \\
\hline Cons & $\begin{array}{l}\text { - UF fillet length is long } \\
\text { - Substrate warpage control is required } \\
\text { - Ultra-thin die assembly is difficult } \\
\text {-Small gap/fine pitch joining is difficult }\end{array}$ & $\begin{array}{l}\text { - Tact time is long } \\
\text { - SMD is jointed to FC separately } \\
\text { - Equipment investment is big } \\
\text { - Process control is difficult (UF void etc.) }\end{array}$ \\
\hline
\end{tabular}

* OBAR: Over-bump Applied Resin 
進める際は，パッケージレベルでSi Interposer やDieの厚み やはんだ組成などの最適化を行うことが重要である。

\section{C4NP (C4 New Process) ${ }^{16)}$ and IMS (Injection Molded Solder) ${ }^{17}$ 技術}

Table 2 は, バンプのはんだ組成が BEOL の層間絶縁膜に 及ぼす影響を確認した結果である。Agの含有量を少なく することで冷却時の CTE ミスマッチに起因して発生する層 間絶縁膜剥離の発生率は低減し, dieの反り量も小さくな ることが確認できる。4章でも述べたが，接合時に使用す るはんだ組成の最適化は接合部へのストレス低減に非常に 有効である。よって, はんだ組成の自由度が高く, 微細化 に対応できるバンピング技術の開発が求められている。 C4NPは，IBMが開発したウエハバンピング技術で，モー ルドと呼ばれる半球状の穴が開いたガラス基板に溶融はん だを溶かし込み，それをウエハ側に転写することでバンプ を形成する技術である。幅広く使われている電気めっき法 によるウエハバンピングの場合，基本的に 2 元系までしか 刘応できないうえにはんだ組成が限定されるのに対し， C4NPは，最適な組成のはんだバンプを自由に形成できる 点, 低コスト化が可能で微細ピッチにも対応しているとい

Table 2. Peak warpage and the number of parts with damage observed by CSAM, for various alloys and cooling rates near room temperature ${ }^{18)}$

\begin{tabular}{|c|c|c|c|}
\hline \multirow{2}{*}{$\begin{array}{l}\text { Ag content } \\
(\text { weight } \%)\end{array}$} & \multirow{2}{*}{$\begin{array}{c}\text { DCWM peak } \\
\text { warpage } \\
\text { (arb. units) }\end{array}$} & \multicolumn{2}{|c|}{$\begin{array}{c}\text { CSAM data } \\
\text { (parts affected/parts inspected) }\end{array}$} \\
\hline & & Regular cooling & $10 \times$ faster cooling \\
\hline 2.2 & 1.00 & $2 / 17$ & $45 / 73$ \\
\hline 1.3 & 0.92 & $3 / 17$ & $4 / 74$ \\
\hline 1.2 & 0.82 & $0 / 15$ & $3 / 75$ \\
\hline 1.0 & 0.80 & $0 / 15$ & $1 / 74$ \\
\hline 0.3 & 0.69 & $0 / 15$ & $1 / 74$ \\
\hline 0.0 & 0.61 & $0 / 15$ & $0 / 74$ \\
\hline $\mathrm{SnPb}$ & 0.40 & $0 / 45$ & NA \\
\hline
\end{tabular}

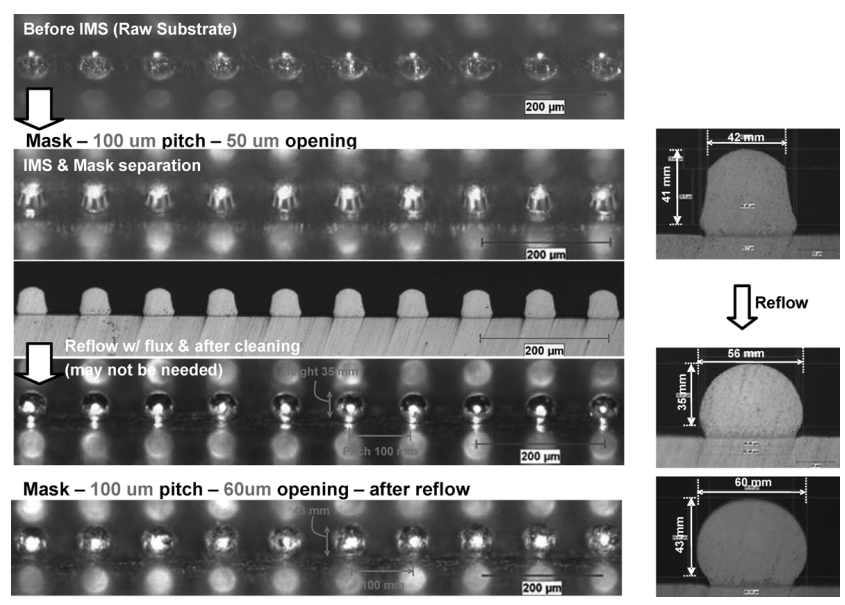

Fig. 7 Solder bumping on substrate with IMS technology (100 $\mu \mathrm{m}$ pitch)
う点で優れている。IMS は，C4NPの技術を応用したプリン 卜配線板へのはんだバンプ形成技術で，C4NPのはんだ充 填用ヘッドを使い，フィルムマスクを通して，プリント配 線板上にはんだバンプを形成することができる。Fig. 7 は, $100 \mu \mathrm{m}$ ピッチの基板に対して IMS で形成したはんだバンプ であるが, $100 \mu \mathrm{m}$ ピッチ以下の基板に対しても，安定した はんだバンプ形成が可能である。また，フィルムデザイン を変更することで，供給するはんだ量を変更することも可 能であり，さらに，C4NP同様，はんだ組成を自由かつ容 易に変更できる点でも優れている。このように，CPIを考 慮したマイクロバンプ接合技術を確立するためには，はん だ組成を自由に変更できる技術が今後は必要不可欠となる と考えられる。

\section{6. まとめ}

さらなるヒューマンライフの向上を目指し，半導体デバ イスは今後も進化し続けていかなければならない。微細化 に対応したバンプ接合技術は，次世代の半導体パッケージ ングを支える重要な技術の1つであるが，本技術を確立す るためには，個々の要素技術開発だけでなく，パッケージ 全体を考慮した幅広い視点にたって，材料・構造・プロセ スなどの最適化に取り組んでいくことが重要であるといえ る。

(2011.5.28-受理)

\section{文献}

1) 傳田精一：“三次元実装のための TSV 技術, ” 工業調査会, pp. 11-12, 2009

2) ITRS: "The International Technology Roadmap for Semiconductors," 2007

3) L. F. Miller: "Controlled Collapse Reflow Chip Joining," IBM Journal of Research and Development, Vol. 13, pp. 239-250, 1969

4) J. Lau, et al.: "Feasibility Study of a 3D Integration System-in Packaging (SiP) from $300 \mathrm{~mm}$ Multi-Project Wafres (MPWs)," International Conference on Electronics Packaging 2011, 2011

5) T. C. Chang, et al.: "Reliability Characterization of $20 \mu \mathrm{m}$ Pitch Microjoints Assembled by a Conventional Reflow Technique," International Conference on Electronics Packaging 2011, 2011

6) K. Sakuma, et al.: "IMC Bonding for 3D Interconnection," 59th ECTC, pp. 864-871, June 2010

7）折井靖光，佐久間克幸，末岡邦昭，小原さゆり，松本圭 司，鳥山和重，青木豊広：“3 次元積層における IMC 接合の 信頼性評価,” Mate 2011, pp. 131-134, February 2011

8) S. Kohara, et al.: "Thermal Stress Analysis of 3D Die Stacks with Low-Volume Interconnections," IEEE CPMT Symposium Japan, No. 10-3, August 2010

9) JEDEC, JEP156: “Chip-Package Interaction Understanding, 
Identification and Evaluation," March 2009

10) D. C. Edelstein: "Extendability of $\mathrm{Cu} /$ Low-k/Airgap BEOL," $214^{\text {th }}$ ECS meeting (the Electrochemical Society), No. 2073, 2008

11) 2005 Semiconductor Materials Outlook, p. 363

12) Y. Orii, et al.: "Ultrafine-Pitch C2 Filip Chip Interconnections with Solder-Capped Cu Pillar Bumps," Proceedings of the $58^{\text {th }}$ Electronic Components and Technology Conference, pp. 948953, 2009

13) C. Feger, et al.: "The Over-Bump Applied Resign Wafer-Level Underfill Process: Process, Material and Reliability," Proceedings of the $58^{\text {th }}$ Electronic Components and Technology Conference, pp. 1502-1505, 2009

14) M. Koyanagi, et al.: "Future System-on-Silicon LSI Chips,"
IEEE Micro, Vol. 18, No. 4, pp. 17-22, Jul/Aug 1998

15) J. U. Knickerbocker, et al.: "Three-Dimensional Silicon Integration,” IBM J. Res. Dev., Vol. 52, No. 6, pp. 553-570, 2008

16) J. Sylvestre, et al.: "The Impact of Process Parameters on the Fracture of Device Structures during Chip Joining on Organic Laminates," Proceedings of the $57^{\text {th }}$ Electronic Components and Technology Conference, pp. 82-88, 2008

17) Jae-Woong Nah, et al.: "Injection Molded Solder-A New Fine Pitch Substrate Bumping Method," $59^{\text {th }}$ Electronic Components and Technology Conference, 2009

18) J. Sylvestre, et al.: "The Impact of Process Parameters on the Fracture of Device Structures during Chip Joining on Organic Laminates," Proceedings of the $57^{\text {th }}$ Electronic Components and Technology Conference, pp. 82-88, 2008 